[JSRNC 14.4 (2020) 496-510]

JSRNC (print) ISSN 1749-4907

http://doi.org/10.1558/jsrnc.34630

JSRNC (online) ISSN 1749-4915

\title{
RETROSPECTIVE
}

\section{Dark Green Religion: A Decade Later}

\author{
Bron Taylor \\ Department of Religion \\ The University of Florida \\ PO Box 117410, Gainesville, FL 32611-7410, USA \\ bron@ufl.edu
}

\begin{abstract}
I wrote the following reflections in the hope they will encourage further research and debate about the phenomena I explored in Dark Green Religion: Nature Spiritualty and the Planetary Future. These reflections are adapted from the 'Vorwort zur deutschen Neuausgabe: Dunkelgrüne Religion-Zehn Jahre danach', with which I introduced the German edition. ${ }^{1}$
\end{abstract}

The motion picture Avatar was written and directed by James Cameron and released in December 2009. Set on Pandora, a lushly vegetated moon circling a distant star, the film depicted the $\mathrm{Na}^{\prime} \mathrm{vi}$, the moon's aboriginal people, in an against-all-odds struggle to defeat human invaders who, having destroyed their Earthly habitat, were hellbent on taking the mineral wealth of Pandora. The film's crescendo was a furious battle in which the Na'vi, several human allies who had come to respect and love the Na'vi, and a host of fierce Pandoran creatures, all united to repel the imperial invaders.

Like most viewers, I found the bio-luminescent landscape of Pandora awe-inspiring and the devastation from the warfare emotionally wrenching. I also immediately recognized that, in its depiction of $\mathrm{Na}^{\prime} \mathrm{vi}$ spirituality, the film exemplified what I wrote about in Dark Green Religion (henceforth DGR for the book, dgr for the phenomena).

1. Bron Taylor, Dunkelgrüne Religion (trans. Kocku von Stuckrad; Leiden: Wilhelm Fink, 2020), ISBN: 978-3-7705-6491-0. Originally published in English as Dark Green Religion: Nature Spiritualty and the Planetary Future (Berkeley \& Los Angeles: University of California Press, 2010), ISBN: 978-0-5202-6100-6. 
On the one hand, the Na'vi perceived Pandora to be a Gaia-like network of organisms, all of whom were essential to the flourishing of life within the moon's biosphere. On the other hand, the Na'vi were engaged in what could be called relational animism: they considered themselves to be kin to, and in communication if not also communion with, all Pandoran life.

Perceptions of the biosphere as a sacred, Gaia-like superorganism, and a value system rooted in felt kinship and respect for all living things, is typical of dgr. As is the case with the diverse social phenomena I analyzed in DGR, some characters in the film understood the Pandoran systems religiously while others understood them scientifically. The Na'vi, for example, personified the Pandoran system as the goddess Eywa, while the scientists who arrived with the invading forces to study the Na'vi understood this system scientifically, as a bio-neurological network. Still others blended these understandings.

Indeed, the boundaries between religious and scientific perceptions became more fluid as the humans who studied and worked with the $\mathrm{Na}^{\prime}$ vi gained respect for them and their knowledge systems. In this, the film reflected the respect for indigenous peoples that is common among those expressing and promoting dark green spiritualities. This has resulted, in no small measure, from scientific understandings of how the 'traditional ecological knowledge' of indigenous peoples, and their spiritual beliefs and practices, are often entangled, having co-evolved in ways that tend to promote resilient and sustainable socioecological systems (also known as biocultural systems). ${ }^{2}$

I became especially interested in Avatar because it exemplified dgr, profoundly moved many audience members, and rapidly became the highest-grossing film of all time, suggesting it might significantly contribute to the spread of dark green spirituality and ethics (Taylor 2013a). ${ }^{3}$ Subsequent research showed that those moved by it typically expressed a longing for a life in harmony with nature, sadness and anger at the accelerating decline of Earth's ecosystems, and a desire to engage in conservation efforts (Istoft 2013; Holtmeier 2013; Gould, Ardoin, and Hashimoto 2013). Equally interesting was Cameron's evangelical motive

2. Socioecological and biocultural systems are synonymic notions for the idea that cultural and biological systems co-evolve and are reciprocally influential. These notions underly scientific understandings about how the 'traditional ecological knowledge' or 'knowledge systems' of indigenous peoples exemplify such coevolutionary processes. For seminal sources, see Berkes 2017 [1999]; Berkes, Colding, and Folke 2000; Reichel-Dolmatoff 1976; Roy, Parkes, and Bicker 2000; Nelson and Shilling 2018; Stepp, Wyndham, and Zarger 2002; and Steward 1977.

3. For analysis of its financial success and global reach, see Rust 2013. 
for making the film. After receiving Golden Globe Awards for Best Director and Best Picture, he explained that through the story and the 'magic' of cinema he sought to awaken audiences to how 'everything is connected, all human beings to each other, and us to the Earth' so they would appreciate and defend the 'miracle of the world that we have right here' (Associated Press 2010).

After observing the film and studying its reception, in Avatar and Nature Spirituality, I wondered 'if the film was evidence that global, cultural receptivity to the ideas prevalent in dark green religion was even more profound than I had previously thought' (Taylor 2013a: 5). Moreover, I questioned whether 'Avatar would prove to be the most effective "dark green" propaganda yet produced' (Taylor 2013a: 5). This is certainly Cameron's hope. Indeed, he is producing and directing four Avatar sequels, which are slated to be released every two years beginning in late 2022. I further wondered whether the film and its reception might provide further evidence for my speculation in DGR that we might be witnessing the nascent stages of a new global nature religion emerging in such cultural creativity.

This might seem far-fetched. But is it?

When presenting lectures about dgr I often begin by noting that Charles Darwin, at the end of On the Origin of Species, asserted that there is 'grandeur' in an evolutionary understanding of the beauty and diversity of the world (Darwin 2003 [1859]: 913). I then suggest that in this passage Darwin offered a science-based meaning system as an alternative to the world's predominant religions. I then ask the audience two questions: If you had been present when the Axial Age prophets and gurus were teaching, would you have predicted that, millennia later, their devotees would have captured the fealty of large proportions of the human community? If there were a new global religious movement unfolding today that would become one of the most prevalent spiritual movements in the world, would you recognize it? After posing these questions I suggest that such a movement may well be emerging and explain that my intention is to provide them with the examples, and analytic lenses, that are needed to bring it into view.

During these lectures, after explaining how the terms 'religion', 'spirituality', and 'nature religion' can be understood and analytically deployed, I review diverse examples of individuals and groups who are expressing and promoting such spiritualities. These examples include scientists, museum and aquarium curators, politicians, diplomats, artists, writers, filmmakers, photographers, mountaineers, surfers, gardeners, teachers, and environmentalists. Some of these actors believe in the 
existence of non-material divine beings while others are agnostic or atheistic. Regardless of whether those who are promoting a dark green cultural transformation are conventionally religious or naturalistic, they all integrate evolutionary and ecological understandings into their worldviews. Most of them also report having had experiences of awe and wonder in natural phenomena, view themselves as belonging to, rather than being separate from (let alone superior to) nature, and express a conviction that our species has an ethical obligation to protect Earth's diverse species and ecosystems.

Some of the examples I provide during lectures appear in DGR. Others emerged, or I only learned about, after its publication. Although in DGR I spent considerable time looking at dark green spirituality in popular culture, since then I have explored in more depth the contested and evolving nature-related ideologies and spiritualities expressed by the creatives at the Walt Disney company. This work included analysis not only of its theatrical films but its theme parks, and especially the naturereverencing themes presented during performances at Disney's Animal Kingdom. Since 2017 such themes have been promoted at a new section of the park popularly known as Avatarland. Disney is even teaching the 'intrinsic value of nature', according to the Disney Vice President leading DisneyNature, a new documentary film division that was established in 2008 (Taylor 2019b).

An especially creative example of dgr I discovered, the very month $D G R$ was first printed, is John Boswell's music videos. Boswell uses autotune technology to change spoken words of world-renowned scientists-including Carl Sagan, Richard Feynman, and Jane Goodall, as well as the beloved nature documentarian David Attenborough-into songs that he wrote for them. Then he mixes these songs with instrumental music and stunning images of the universe and biosphere. Without a doubt, Boswell is creating these videos to evoke awe and wonder toward the cosmos in general and Earth's living systems in particular. Although most of the voices included are from scientists who are atheists or atheism-leaning agnostics, Boswell's videos express reverence for nature and urge proenvironmental innovation and conservation. ${ }^{4}$

Novels have also, often, expressed dark green themes (Kingsolver 2012; Atwood 2010). Since the publication of DGR none have done so more directly and influentially than The Overstory, for which Richard Powers was awarded the Pulitzer Prize for Fiction in 2019 (Powers 2018).

4. Among the best examples are 'We're all Connected', and 'The Unbroken Thread'. See Melody Sheep 2013 and Melody Sheep n.d.

(c) Equinox Publishing Ltd 2021. 
After receiving the prize, Powers commented, 'The book is indeed filled with what Bron Taylor would call dark green religion' (Hamner 2018). ${ }^{5}$ His diverse characters included radical environmentalists and arborists who, in various ways, expressed Gaian ecological metaphysics and animistic perceptions about the consciousness and communicative abilities of trees. According to Powers, for many of the novel's characters, 'treeconsciousness is a religion of life, a kind of bio-pantheism'. Moreover, the spirituality of many of his characters was entirely naturalistic; as Powers put it, theirs was 'a religion without metaphysics'. For others, it was based instead on, or enhanced by, mystical experiences of communication and communion with trees. Whatever their metaphysics, the novel's central characters perceived that trees, and life itself, are all trying to communicate with our species. Indeed, nature in whole and in part is agential, it 'wants something from us'.

In interviews Powers has acknowledged that he also wants to awaken something in us, 'to resurrect a very old form of tree consciousness, a religion of attention and accommodation, a pantheism of sorts'. This would, he hopes, lead readers to reject anthropocentric hubris and to see themselves as related, as kin, to all other organisms, and as belonging to 'the life-process as a whole'. This, he thinks, would redound in respect and reverent care for nature. Recognizing that storytellers have for millennia shaped understandings of the human place in and responsibilities to the world, Powers stated that novelists have a similar role to play, providing meaningful myths that awaken reverence for life. This, he thinks and hopes, could help to avert ecological catastrophe.

In DGR I discussed what I called 'eye-to-eye epiphanies', namely, perceptions of communication, and kinship feelings, that some people have when looking into the eyes of a non-human animal. After its publication in English, a number of readers shared with me their own experiences of connection with other organisms through such a gaze.

There are many public examples of such experiences. One of these was aired on 'To the Best of our Knowledge' (henceforth TTBOOK), an audio program produced in Wisconsin (USA) and distributed as a streaming podcast by Public Radio International. The episode, titled 'The Secret Language of Trees', aired in April 2018. It featured an interview with Powers as well as with forest ecologist Suzanne Simard. Her research about tree communication had inspired one of Powers' main characters (Strainchamps 2018), as did a book by the German forester Peter

5. All quotes in this paragraph are from Everett Hamner's interview. For more on the novel's affinities with dgr, as well as for the living characters I have written about that he apparently drew on in his novel, see Taylor 2019a.

(c) Equinox Publishing Ltd 2021. 
Wohlleben, whose international bestselling book, first published as Das geheime Leben der Bäume: was sie fühlen, wie sie kommunizieren; der Bildband (Wohlleben 2016a) and soon afterward as The Hidden Life of Trees: What They Feel, How They Communicate (Wohlleben 2016b). ${ }^{6}$ The creatives producing TTBOOK were already familiar with DGR because Stephen Paulson, the program's executive producer, had interviewed me about it in 2010 for a program titled 'Sacred Nature' (Fleming 2010). In 2018, the Chicago-based Center for Humans in Nature, whose leaders had asked me to write essays for them in part because they were aware of my argument in DGR and felt some affinity with such spirituality, launched a 'Kinship Project'. ' The affinities between the leaders of the Center and the creatives at TTBOOK led to their collaboration on another audio program, this one titled, 'Eye-to-Eye Animal Encounters' (Strainchamps 2020a). The program began with an interview between the program's host, Anne Strainchamps, and the center's creative director, Gavin Van Horn, who mentioned that the show's theme was inspired by the 'eye-toeye' analysis in DGR. ${ }^{8}$ The Kinship Project is also developing another series of interviews, and a book, which will, little doubt, present further expressions of dgr.

Also noteworthy, since the publication of $D G R$, are efforts to formally establish religious organizations to advance dark green spiritualities and values. In the United States, Erik Assadourian, a Senior Fellow of the globally influential Worldwatch Institute, founded Gaianism (Gaianism 2020). In so doing he took inspiration from the Gaia Hypothesis that was advanced by James Lovelock and Lynn Margulis (Lovelock 1972; Lovelock and Margulis 1974; Lovelock 1979). The hypothesis holds that the biosphere is analogous to a living being because it functions as a selfregulating organism that maintains the conditions necessary for life. Similarly, Guy Lane, an Australian environmental scientist, founded 'Vita Religion, which teaches that all the living things on Earth are parts of a single life form called Vitae-planeta - the Living Planet' (Vita 2020). The Church of Deep Ecology, which along with Vita Religion has secured tax exempt status as a religion, provides a third example (Church of

6. Other sources that inspire a kind of naturalistic animism, which Powers may have drawn on, include Tudge 2006; Nadkarni 2008; Hall 2011; Kimmerer 2013; and Haskell 2012. Works published after Powers could have drawn on them in his novel include Mancuso 2018 and Haskell 2017. The popularity of Haskell's books is shown by the numerous awards they have received.

7. For these essays, see Taylor 2013b, 2017.

8. For an overview about the program which, like Van Horn's comments during the interview mentioned the influence of my eye-to-eye trope, see Strainchamps 2020b. 
Deep Ecology 2020). Although rooted in the sciences, these nature religions express a conviction that the biosphere is sacred and defending life is a moral obligation.

It may also be significant that the founders of both Gaianism and Vita Religion have recognized their affinity with dgr and have taken some inspiration from it. Similarly, many readers and those who have attended my lectures have expressed their affinity with dgr. Some correspondents also related that, upon learning that such spirituality is multi-form and more widespread than they had previously realized, they felt less lonely and more hopeful. Conversely, some conservative religious individuals have used DGR as evidence to buttress their dire warnings about the spread of nature religions, which they consider to be spiritually and politically dangerous, threatening both the religiously faithful and true religion (Wanliss 2011; Provan 2013). ${ }^{9}$

It is clear that cultural creatives have continued to promote dark green spiritualities and values. So have many scholars, including a collaboration launched by scholars of diverse disciplines to establish a new, ecocentric journal, to bring to a wider audience the diverse scholarly paths to such perspectives. ${ }^{10}$ But it is the 'Rights of Nature movement', as it is now being called in documentaries, that may become the most important political expression of dgr. ${ }^{11}$ In DGR I discussed some of the seminal figures who have been advancing the idea that rights should be

9. See also Cornwall Alliance 2020.

10. This is an initiative I have been involved in, including by contributing to the journal's initial prolegomena and to a 'Statement of Commitment to Ecocentrism', which has been signed by nearly a thousand scholars and environmental advocates, including many famous ones; see Washington et al. 2017, 2020. For an effort to promote ecocentrism within United Nations programs that are responsible for developing global environmental policies, see Taylor et al. 2020. Many more examples wherein scholars have been developing their own fields in ways that have affinity with dgr could be provided, including those emerging under these tropes: the 'new animism', 'new materialism', and 'environmental humanities'. Many of those whose identities nest under these tropes have affinity with what I have called dgr. In the kind of historical perspective provided in DGR, and in the works of Kocku von Stuckrad (discussed presently), however, it seems to me that what such scholars are doing is not so much new, but new to them and their fields.

11. Two documentaries focus on this trend. 'The Rights of Nature: A Global Movement' provides an excellent overview and was released in English and Spanish; see Goeckeritz, Crimmel, and Berros 2018. The second documentary with such a focus is 'Invisible Hand'. It examined the massive protest against an oil pipeline by the Standing Rock Sioux (a North American Indigenous Nation) and their allies, while linking these campaigns to the global rights of nature movement. It was produced by the activist actor Mark Ruffalo and it premiered on September 2020; see Ruffalo 2020.

(c) Equinox Publishing Ltd 2021. 
conferred on nature, including Christopher Stone (1974), Roderick Nash (1989), and Cormac Cullinan (2003). ${ }^{12}$ The basic idea is that naturevariously understood to include individual organisms, species, ecosystems, and natural entities such as rivers and mountains-should be allowed to exist and flourish; and that laws and enforcement mechanisms should be established to ensure these rights are respected. Moreover, the notion typically avers that if governments charged with these responsibilities fail then citizens should be empowered to sue to prevent the violation of such rights through the courts-or if it is too late to prevent the harm, to require acts of restorative justice. Not incidentally, those promoting these rights also usually have affinity with dgr and express this to varying degrees. This often involves drawing on the traditions of, and expressing solidarity with, specific indigenous people with whom they are, also often, in alliance.

The most significant example of efforts to expand the notion of rights to nature took place in 2008 when Ecuador became the first nation to enshrine such rights, with remarkably strong language, in their constitution. ${ }^{13}$ As has been the case in many of the subsequent efforts to establish such rights, this effort was inspired in part by the aforementioned legal theorists (especially the American Stone and the South African Cullinan), as well as by indigenous activists, who maintain that their traditions enjoin respect for natural entities, which many of them understand as persons (and sometimes, as deities). In the Andes, for example, many indigenous societies have long considered 'Mother Earth', known there by many as 'Pachamana', as a living being.

In 2010, Bolivia followed Ecuador's lead when it passed laws with very similar intent and language. Also that year, Bolivia hosted a conference that issued a 'Universal Declaration on the Rights of Mother Earth'. The underlying strategy was much like that behind the Earth Charter (discussed in DGR) to gain United Nations ratification of this declaration. Although the United Nations has not endorsed such rights and is unlikely to do so anytime soon, the effort was influential. In 2009, for example, the UN declared 22 April as 'International Mother Earth Day' and soon afterward it established a Harmony with Nature Programme (United Nations 2009), which has often noted that many people endorse the notion that nature has rights. Moreover, in 2012, the

12. For less well-known books that nevertheless illustrate the international interest in the idea, see Leimbacher 1988 and Acosta and Martinez 2009.

13. For the most stunning passage, see the end of Taylor 2011, which also highlighted how, just like other forms of dgr, some conservative religionists view this development as spiritually dangerous.

(c) Equinox Publishing Ltd 2021. 
International Union for the Conservation of Nature agreed to consider the Rights of Nature in its programs and decision making (see Earth Law Center 2020). Such rights, and the role of indigenous peoples in having values that cohere with them, are also increasingly incorporated into scientific reports issued under the UN umbrella (Boyd 2017). ${ }^{14}$

Between 2010 and 2020, many other legislative initiatives and legal rulings have advanced the notion of nature's rights, and this increasingly includes municipalities, which are able to pass such measures to stop enterprises that they consider environmentally destructive. Among the most significant examples took place in 2017 when New Zealand, through negotiations with its indigenous peoples, granted personhood and legal status to the Whanganui River. The same year, court rulings in India recognized the Ganga and Yamuna Rivers as persons and rights holders (although later court rulings reversed this landmark decision). In 2018 and 2019, rights were established for various rivers and watersheds, including all the rivers in Bangladesh, and a number of watersheds in Uganda and Colombia. Kindred efforts are underway in other countries in Africa and Latin America. Although these laws are difficult to enforce, often ignored, and sometimes overturned, they do provide leverage to proenvironmental civil society actors. The movement has had some success in changing environment-related jurisprudence and aims to transform international environmental laws as well ( $\mathrm{O}^{\prime}$ Donnell and Talbot-Jones 2018; Wilson and Lee 2019). From this vantage point it appears that these efforts and strategies-which are powered in no small measure by those with dark green sentiments and values-will continue to gain traction and influence. They also, of course, fuel the growth of dark green spiritualities.

The preceding examples complement and strengthen the evidence advanced in the first, English edition of $D G R .{ }^{15}$ Although many readers have found this work compelling, as one who values mixed-methods research I have considered my findings in DGR to be an evidence-based working hypothesis that deserves further critical investigation. Consequently, subsequent to the publication of DGR, I orchestrated a multiyear comprehensive review of social scientific research, both qualitative and quantitative, to further assess the perceptions I had arrived at

14. For a pithy timeline of events, see Community Environmental Legal Defense Fund 2020, as well as Hillebrecht and Berros 2017. For evidence that such notions are gaining attention in mainstream scientific circles, see Chapron, Epstein, and LópezBao 2019.

15. For additional examples of phenomena not discussed in $D G R$, including music and videos, see Taylor 2020b. 
through my own research. This review found that worldviews and values akin to what I have called dgr are indeed gaining cultural traction and moreover, they do appear to lead to proenvironmental behavior (Taylor, Van Wieren, and Zaleha 2016). ${ }^{16}$ I have also designed my own survey instrument to test whether the traits that are typical of dgr are associated with proenvironmental behavior; the first study that included this instrument found that they are (Taylor, LeVasseur, and Wright 2020). ${ }^{17}$ The interest among scholars to translate the book or parts of it into other languages, including Mandarin, Spanish, Portuguese, and Turkish, or to engage with it in scholarly work, further suggests that, given what they see in their own regional contexts, some scholars have found the argument and evidence in DGR to be compelling, or at least, worth further investigation.

Among these examples is the interest in translating DGR that Kocku von Stuckrad expressed to me a couple years ago. Von Stuckrad is an expert in the entanglement and reciprocal influences of religion and science, especially in Europe and America during the nineteenth and early twentieth centuries. His own scholarship is synergistic with my own, as for example in The Scientification of Religion (von Stuckrad 2014). While von Stuckrad and I examined some of the same individuals in our books, my focus in DGR has been especially on the ways science and religion have been co-evolving since the mid-twentieth century, a time to which environmental historians trace the 'great acceleration' of anthropogenic environmental change, which some scholars consider the advent of a new, human-dominated epoch, and are calling the Anthropocene (McNeill and Engelke 2014; Steffen et al. 2015). These accelerating and destructive trends have themselves shaped the increasing environmentalist ethos that characterizes dark green spiritualities.

I surmise that part of why von Stuckrad has been interested in the evidence and argument in $D G R$ is because it suggests that the spadework of both heterodox and mainstream scientists that he has spotlighted has not only been influential but, as we can now see, has laid the foundation for exceptionally important and influential trends. As he put it, 'veneration of nature as a consequence of ecological and biological thinking is widespread in Europe and North America today. Indeed, with Bron

16. The review also found that, contrary to the perceptions and hopes of some scholars and religionists, there is no compelling evidence of a significant 'greening' of the world's predominant religions. For a history of the scholarly ferment over religion and environmental behavior, see Taylor 2016.

17. My dgr-focused scale was combined in this research with an environmental humility instrument developed by my collaborators. 
Taylor we can even argue that nature-based spirituality is a form of religion that is spreading significantly on a global scale' (von Stuckrad 2014: 87). He then provocatively (and I think accurately) contended that the 'discursive constellations' in his book 'are the most important roots of contemporary nature spirituality' (von Stuckrad 2014: 87). In his most recent book, Die Seele im 20. Jahrhundert: Eine Kulturgeschichte (The Soul in the 20 ${ }^{\text {th }}$ Century: A Cultural History), von Stuckrad (2019) further elaborated on these discursive arrangements, focusing on the important role that terms such as animism, nature, consciousness, and spirituality are playing in religious change. Readers of all three of these works will see that we concur about the roots of these phenomena, and apparently, von Stuckrad also finds compelling the portrait of them that I have provided and the evidence that they are now spreading globally.

All this raises the sorts of questions that I often ask audiences to ponder at the end of my dgr-focused lectures: What worldviews do you think the majority of humankind will embrace 500 years from now, or in one or more millennia? Will it be something akin to what I have called dgr? Will the most prevalent religions today have dramatically declined (or died out)? Will increasing proportions of the human population embrace scientific understandings of the origins and evolution of the universe and biosphere and weave them into new, spiritually fulfilling cosmovisions? Will the collapse of socioecological systems precipitate or accelerate such changes? Will new fusions of science and spirituality eventually lead to biocultural systems that are healthy, resilient, and sustainable?

It seems to me that in an age wherein scientists express increasing alarm about extinctions and the increasing likelihood famine, scarcitydriven violence, and even the collapse of socioecological systems, that it makes sense to consider such questions. One thing seems certain: the world as we know it is ending and, unless we rapidly change our perceptions, values, and behaviors, this ending will not be happy (Taylor 2020a). Indeed, based on decades of research including in DGR, if the great acceleration of environmental destruction and species extinctions are to be slowed and halted; if 'another world is possible' - to borrow a slogan from the worlds' civil society actors who are resisting the current destructive inertia-then I think the extant evidence is that dark green spiritualities will likely have something to do with it (Taylor et al. 2020). 


\section{References}

Acosta, Alberto, and Esperanza Martinez (eds.). 2009. Derechos De La Naturaleza-El Futuro Es Ahora (Quito, Ecuador: Abya-Yala).

Associated Press. 2010. 'James Cameron's "Avatar" Wins Big at Golden Globes'. Access Hollywood (18 January). Online: https:/ / www.accessonline.com/articles / james-camerons-avatar-wins-big-at-golden-globes-81039.

Atwood, Margaret. 2010. The Year of the Flood: A Novel (London: Virago Press; original edn, London \& New York: Bloomsbury, 2009).

Berkes, Fikret. 2017 [1999]. Sacred Ecology: Traditional Ecological Knowledge and Resource Management (New York: Routledge, 4th edn; original edn, Philadelphia, PA: Taylor \& Francis).

Berkes, Fikret, Johan Colding, and Carl Folke. 2000. 'Rediscovery of Traditional Ecological Knowledge as Adaptive Management', Ecological Applications 10.5: 1251-62. Doi: https://doi.org/10.1890/1051-0761(2000)010[1251:ROTEKA]2.0. $\mathrm{CO} ; 2$.

Boyd, David R. 2017. The Rights of Nature: A Legal Revolution That Could Save the World (Toronto, ON: ECW Press).

Chapron, Guillaume, Yaffa Epstein, and José Vicente López-Bao. 2019. 'A Rights Revolution for Nature: Introduction of Legal Rights for Nature Could Protect Natural Systems from Destruction', Science 363.6434: 1392-93. Doi: https://doi.org/10.1126/science.aav5601.

Church of Deep Ecology. 2020. 'Church of Deep Ecology'. Online: http:// www.thechurchofdeepecology.org/.

Community Environmental Legal Defense Fund. 2020. 'Advancing Legal Rights of Nature: Timeline'. Online: https://celdf.org/advancing-community-rights/ rights-of-nature/rights-nature-timeline/.

Cornwall Alliance. 2020. 'Cornwall Alliance: For the Stewardship of Creation'. Online: at https: / / cornwallalliance.org/.

Cullinan, Cormac. 2003. Wild Law: A Manifesto for Earth Justice (Totnes: Green).

Darwin, Charles. 2003 [1859]. On the Origin of Species and the Voyage of the Beagle (with an Introduction by Richard Dawkins) (New York: Knopf, Everyman's Library).

Earth Law Center. 2020. 'Universal Declaration of River Rights'. Online: https:// www.earthlawcenter.org/river-rights.

Fleming, Jim. 2010. 'Sacred Nature'. To the Best of Our Knowledge (Wisconsin Public Radio, Public Radio International, 2 May). Online: https:/ / www.ttbook.org/ show/sacred-nature.

Gaianism. 2020. 'Gaianism: A Philosophical Path through an Ecologically Unstable Time'. Online: http://gaianism.org/.

Goeckeritz, Isaac, Hal Crimmel, and MaríaValeria Berros. 2018. 'The Rights of Nature: A Global Movement, 2018'. Online: https://youtu.be/kuFNmH7lVTA, or Spanish version, 'Los derechos de la Naturaleza'. Online: https://youtu.be/ RupkZM8dV14.

Gould, Rachelle, Nicole M. Ardoin, and Jennifer Kamakanipakolonahe'okekai Hashimoto. 2013. 'Transposing the Coversation in Popular Idiom: The Reaction to Avatar in Hawai'i', in Taylor 2013a: 95-122.

Hall, Mathew. 2011. Plants as Persons: A Philosophical Botany (Albany: State University of New York Press). 
Hamner, Everett. 2018. 'Here's to Unsuicide: An Interview with Richard Powers', Los Angeles Review of Books (7 April). Online: https://lareviewofbooks.org/ article/heres-to-unsuicide-an-interview-with-richard-powers/.

Haskell, David George. 2012. The Forest Unseen: A Year's Watch in Nature (New York: Viking).

- 2017. The Songs of Trees: Stories from Nature's Great Connectors (New York: Viking).

Hillebrecht, Anna Leah Tabios, and María Valeria Berros (eds.). 2017. Can Nature Have Rights? Legal and Political Insights, RCC Perspectives, No. 6 (Munich, Germany: Rachel Carson Center).

Holtmeier, Matthew. 2013. 'Post-Pandoran Depression or Na'vi Sympathy: Avatar, Affect, and Audience Reception', in Taylor 2013a: 83-93.

Istoft, Britt. 2013. 'Avatar Fandom, Environmentalism, and Nature Religion', in Taylor 2013a: 61-82.

Kimmerer, Robin Wall. 2013. Braiding Sweetgrass: Indigenous Wisdom, Scientific Knowledge and the Teachings of Plants (Minneapolis, MN: Milkweed).

Kingsolver, Barbara. 2012. Flight Behavior: A Novel (New York: Harper, 1st edn).

Leimbacher, Jorg. 1988. Die Rechte Der Natur (Basel Frankfurt am Main: Helbing \& Lichtenhahn).

Lovelock, James. 1972. 'Gaia as Seen through the Atmosphere (Letter to the Editors)', Atmospheric Environment 6: 579-80. Doi: https://doi.org/10.1016/00046981(72)90076-5.

. 1979. Gaia: A New Look at Life on Earth (Oxford \& New York: Oxford University Press).

Lovelock, James, and Lynn Margulis. 1974. 'Atmospheric Homeostasis by and for the Biosphere: The Gaia Hypothesis', Tellus 26.1-2: 2-10. Doi: https://doi.org/ 10.3402/tellusa.v26i1-2.9731.

Mancuso, Stefano. 2018. The Revolutionary Genius of Plants (New York: Atria Books, Simon \& Schuster).

McNeill, John Robert, and Peter Engelke. 2014. The Great Acceleration: An Environmental History of the Anthropocene since 1945 (Cambridge, MA: The Belknap Press of Harvard University Press).

Melody Sheep. 2013. Best of Symphony of Science. Band Camp, Digital Album. Online: https://melodysheep.bandcamp.com/album/best-of-symphony-of-science.

. n.d. 'Symphony of Science'. Online: https://www.symphonyofscience.com/.

Nadkarni, Nalini. 2008. Between Earth and Sky Our Intimate Connections to Trees (Berkeley, CA: University of California Press). Doi: https://doi.org/10.1525/ 9780520933125.

Nash, Roderick Frazier. 1989. The Rights of Nature: A History of Environmental Ethics (Madison, WI: University of Wisconsin Press).

Nelson, Melissa K., and Dan Shilling (eds.). 2018. Traditional Ecological Knowledge (Cambridge, UK: Cambridge University Press).

O'Donnell, Erin L., and Julia Talbot-Jones. 2018. 'Creating Legal Rights for Rivers: Lessons from Australia, New Zealand, and India', Ecology and Society 23.1. Doi: https:/ / doi.org/10.5751/ES-09854-230107.

Powers, Richard. 2018. The Overstory: A Novel (New York: Norton).

Provan, Iain 2013. Convenient Myths: The Axial Age, Dark Green Religion, and the World That Never Was (Waco, TX: Baylor University Press). 
Reichel-Dolmatoff, Gerardo. 1976. ‘Cosmology as Ecological Analysis: A View from the Rainforest', Man 2.3: 307-18. Doi: https://doi.org/10.2307/2800273.

Roy, Ellen, Peter Parkes, and Alan Bicker (eds.). 2000. Indigenous Environmental Knowledge and Its Transformations: Critical Anthropological Perspectives, Studies in Environmental Anthropology (Amsterdam: Harwood Academic).

Rust, Stephen. 2013. 'Avatar: Ecorealism and the Blockbuster Melodrama', in Taylor 2013a: 23-36.

Ruffalo, Mark. 2020. 'Invisible Hand'. 85 minutes. United States. Online: https:// www.invisiblehandfilm.com/.

Steffen, Will, W. Broadgate, L. Deutsch, O. Gaffney, and C. Ludwig. 2015. 'The Trajectory of the Anthropocene: The Great Acceleration', The Anthropocene

Review 2.1: 81-98. Doi: https://doi.org/10.1177/2053019614564785.

Stepp, John R., Felice S. Wyndham, and Rebecca K. Zarger. 2002. Ethnobiology and Biocultural Diversity: Proceedings of the Seventh International Congress of Ethnobiology (Athens, GA: International Society of Ethnobiology \& University of Georgia Press).

Steward, Julian. 1977. Evolution and Ecology (Urbana \& Chicago: University of Illinois Press).

Stone, Christopher D. 1974. Should Trees Have Standing? (Los Altos, CA: William Kaufmann).

Strainchamps, Anne. 2018. 'The Secret Language of Trees', To the Best of Our Knowledge (Wisconsin Public Radio, Public Radio International, 28 April).

Online: https://www.ttbook.org/show/secret-language-trees.

- 2020a. 'Eye-To-Eye Animal Encounters', To the Best of Our Knowledge (Wisconsin Public Radio, Public Radio International, 8 February. Online: https:/ / www.ttbook.org/show/eye-eye-animal-encounters.

. 2020b. 'Sharing Eye-To-Eye Epiphanies with the Animal World', To the Best of Our Knowledge (Wisconsin Public Radio, Public Radio International, 13 February). Online: https://www.ttbook.org/interview/sharing-eye-eyeepiphanies-animal-world.

Taylor, Bron. 2011. 'Debate over Mother Earth's "Rights" Stirs Fears of Pagan Socialism'. Religion Dispatches (20 April). Online: https://religiondispatches. org/debate-over-mother-earths-rights-stirs-fears-of-pagan-socialism/. . (ed.). 2013a. Avatar and Nature Spirituality (Waterloo, ON: Wilfrid Laurier University Press).

- 2013b. 'Salmon Speak—Why Not Earth?', Center for Humans and Nature. Online: https://www.humansandnature.org/earth-ethic-bron-taylor. . 2016. The Greening of Religion Hypothesis (Part One): From Lynn White, Jr. And Claims That Religions Can Promote Environmentally Destructive Attitudes and Behaviors to Assertions They Are Becoming Environmentally Friendly', JSRNC 10.3: 268-305. Doi: https:// doi.org/10.1558/jsrnc.v10i3.29010.

- 2017. 'Evolution and Kinship Ethics', Center for Humans and Nature. Online: https://www.humansandnature.org/evolution-and-kinship-ethics.

. 2019a. 'Animism, Tree-Consciousness, and the Religion of Life: Reflections on Richard Powers' the Overstory', Minding Nature 12.1: 42-47. Online: https://www.humansandnature.org/animism-tree-consciousness-and-thereligion-of-life-reflections-on-richard-powers-the-overstory. 
2019b. 'Rebels against the Anthropocene? Ideology, Spirituality, Popular Culture, and Human Domination of the World within the Disney Empire', JSRNC 13.4: 414-54. Doi: https:/ / doi.org/10.1558/jsrnc.39044.

- 2020a. 'Apocalypse Then, Now-and Future?', Ecocene 1.1:72-84, open access online at http:/ / www.environmentandsociety.org/mml/apocalypse-then-nowand-future. Doi: https://doi.org/10.46863/ecocene.2020.8.

. 2020b. 'Dark Green Religion: Nature Spirituality and the Planetary Future'.

Online: http://www.brontaylor.com/environmental_books/dgr/favorites.html.

Taylor, Bron, Guillaume Chapron, Helen Kopnina, Ewa Orlikowska, Joe Gray, and

John Piccolo. 2020. 'The Need for Ecocentrism in Biodiversity Conservation',

Conservation Biology 34.5: 1089-96. Online: https:/ / conbio.onlinelibrary.wiley. com/doi/10.1111/cobi.13541. Doi: https://doi.org/10.1111/cobi.13541.

Taylor, Bron, Todd LeVasseur, and Jennifer Wright. 2020. 'Dark Green Humility: Religious, Psychological, and Affective Attributes of Proenvironmental Behaviors', Journal of Environmental Studies and Science 10.1: 41-56. Doi: https:/ / doi.org/10.1007/s13412-019-00578-5.

Taylor, Bron, Gretel Van Wieren, and Bernard Daley Zaleha. 2016. 'The Greening of Religion Hypothesis (Part Two): Assessing the Data from Lynn White, Jr., to Pope Francis', JSRNC 10.3: 306-78. Doi: https://doi.org/10.1558/jsrnc.v10i3. 29011.

Tudge, Colin. 2006. The Secret Life of Trees: How They Live and Why They Matter (New York: Penguin Press Science).

United Nations. 2009. 'Harmony with Nature'. Online: http://www. harmonywithnatureun.org/.

von Stuckrad, Kocku. 2014. The Scientification of Religion: An Historical Study of Discursive Change, 1800-2000 (Boston: W. de Gruyter). Doi: https://doi.org/ 10.1515/9781614513490.

. 2019. Die Seele Im 20. Jahrhundert: Eine Kulturgeschichte (Leiden and Paderborn, Germany: Wilhelm Fink/Brill). Doi: https:/ / doi.org/10.30965/9783846764374. Vita. 2020. 'Vita'. Online: https://thinkvita.org/.

Wanliss, James. 2011. Resisting the Green Dragon: Dominion, Not Death (Chattanooga, TN: Cornwall Alliance).

Washington, Haydn, Bron Taylor, Helen Kopnina, Paul Cryer, and John J. Piccolo. 2017. 'Why Ecocentrism Is the Key Pathway to Sustainability', The Ecological Citizen 1.1: 35-41. Online: https://www.ecologicalcitizen.net/article.php? $\mathrm{t}=$ why-ecocentrism-key-pathway-sustainability.

. 2020. 'Statement of Commitment to Ecocentrism'. Online: https://www. ecologicalcitizen.net/statement-of-ecocentrism.php?submit=Sign+our+ Ecocentrism+Statement.

Wilson, Grant, and Darlene May Lee. 2019. 'Rights of Rivers Enter the Mainstream', The Ecological Citizen 2.2: 183-87. Online: https://www.ecologicalcitizen.net/ pdfs/v02n2-13.pdf.

Wohlleben, Peter. 2016a. Das Geheime Leben Der Bäume: Was Sie Fühlen, Wie Sie Kommunizieren; Der Bildband (Munich: Ludwig Verlag).

- 2016b. The Hidden Life of Trees: What They Feel, How They CommunicateDiscoveries from a Secret World (Vancouver, BC: Greystone Books). 